\section{Minutes}

Niall A. Logan, Chairman and

acting Secretary

International Committee on Systematics of Prokaryotes

\title{
Subcommittee on the taxonomy of the genus Bacillus and related organisms
}

\author{
Minutes of the meeting, 6 August 2008, Istanbul, Turkey
}

Minute 1. Call to order. The meeting was called to order by the Chairman, Niall A. Logan, at 11:40 on 6 August 2008 in the Istanbul Convention and Exhibition Centre, Istanbul, Turkey. By agreement, the meeting started 40 min later than scheduled, in order to allow a member to attend the first part of another subcommittee meeting. The Chairman apologized that, owing to illness, no meeting had been held at the IUMS Congress in San Francisco in 2005.

Minute 2. Record of attendance. The members present were Niall A. Logan (Chairman and acting Secretary), Hans-Jürgen Busse, Paul De Vos, Peter Kämpfer and Antonio Ventosa (who had to leave at 12.45 in order to attend another meeting). Apologies for absence were received from Alistair Bishop, Dagmar Fritze, Marc Heyndrickx, Anne-Brit Kolstø, Fergus G. Priest and Leon Rabinovitch. It was noted with regret that inadequacies of Congress organization and signage made it unlikely that any further interested persons would attend for the open session of the meeting.

Minute 3. Minutes of the previous meeting. The minutes of the meeting that was held on 20 July 2002 in Paris, France, had been circulated by email, approved and published [Int J Syst Evol Microbiol 55 (2005), 977-979].

Minute 4. Matters arising. It was noted that the problem of type strains that are covered by patent protection, and therefore not being freely available for study, had been resolved by the Judicial Commission on the International Committee on Systematics of Prokaryotes [Int J Syst Evol Microbiol 58 (2008), 1737-1745; Minute 16]. A. Ventosa requested corrections to some points of detail in the published minutes of the previous meeting: Minute 8 , line 5 , change 'housekeeping enzymes' to 'housekeeping genes'; lines 26 and 27, change '....acid from starch negative, acid from salicin negative...' to '....acid production from starch negative, acid production from salicin negative...'.

\section{Minute 5. Subcommittee composition and function}

(i) Title, purpose and scope of the subcommittee. The title of the subcommittee was discussed. The Chairman questioned whether it should be changed to reflect the subcommittee's scope more clearly; it was agreed that circumscription by order (Bacillales) or family (Bacillaceae) was unworkable, as the former would embrace groups already covered by other subcommittees whereas the latter would exclude aerobic endospore-forming genera such as those in Paenibacillaceae. Likewise, the title 'Subcommittee on the taxonomy of the genus Bacillus and other aerobic endospore-forming organisms' would imply the exclusion of closely related, but non-spore-forming, genera such as Kurthia. It was resolved that the present title be retained.

The role of the subcommittee following the publication of minimal standards was considered; it was agreed that the subcommittee would continue to have roles in revision of minimal standards as necessary, and monitoring their use. It was resolved that e-meetings should be held to address such subcommittee matters between the three-yearly, formal meetings at IUMS congresses.

(ii) Resignations and retirements. The Chairman reported that L. K. Nakamura and R. A. Slepecky had both retired and were no longer participating in subcommittee activities, so that their resignations can be assumed. A. Ventosa confirmed that there is no formal mechanism for retirement from subcommittees. It was also reported that F. G. Priest would retire from his university position in September 2008, and the Chairman undertook to ask him if he wished to continue to serve on the subcommittee.

(iii) Secretarial vacancy. The present Chairman is also acting Secretary, and a new secretary is sought. The Chairman explained that the secretary should also be considered deputy Chairman and so effectively Chairman-elect; indeed, had such a structure existed at the time of the meeting intended to be held at the IUMS Congress in San Francisco in 2005, the meeting could have taken place despite the Chairman's absence. It was resolved that, once some new members had joined the subcommittee, election for the post of secretary would be held at the next meeting of the subcommittee, planned for 2011.

(iv) New members. The Chairman reported that there were three vacancies on the subcommittee, and A. Ventosa advised that there is no statutory limit on subcommittee membership. Two names were put forward, and it was agreed that the Chairman would invite them to join the 
subcommittee. The Chairman wondered whether a new member with expertise on non-spore-forming relatives within the phylogeny of the aerobic endospore-formers, or one with an interest in thermophiles might be desirable, if a suitable person could be identified. It had previously been suggested by H.-J. Busse that a member with an interest in peptidoglycan analysis would be attractive, as this approach to characterization had been ignored too much in the past, and he agreed to investigate this possibility. It was further agreed that, as the current membership of the committee is predominantly European, further new members would be sought from outside Europe.

Minute 6. Minimal standards. The Chairman tabled a draft paper, outlining taxonomic scope and history, and proposed minimal standards. P. Kämpfer suggested, and it was agreed, that this long draft should be revised to shorten it, and that it should be composed of two parts: (i) the minimal standards for publication and (ii) the outline of the scope of the subcommittee, indicating the genera to which the standards apply, and taxonomic history, for inclusion as a supplementary document to the published minimal standards. It was also agreed that both documents should be accessible from the ICSP Subcommittees website. A. Ventosa proposed that a list of taxa with $16 \mathrm{~S}$ rRNA gene sequence accession numbers should be prepared to accompany the minimal standards as supplementary material, and that the published minimal standards should contain a list of 'essential' and 'desirable' characters presented in tabular form for easy reference, as employed in the Recommended minimal standards for describing new taxa of the family Halomonadaceae [Int J Syst Evol Microbiol 57 (2007), 2436-2446]. P. De Vos agreed to prepare the list of taxa with $16 \mathrm{~S}$ rRNA gene sequence accession numbers, and N. A. Logan agreed to prepare the list of 'essential' and 'desirable' characters. A. Ventosa also suggested a strategy for expediting the rapid publication of the minimal standards, with strict deadlines for members to comment upon drafts, and inclusion only of those responding in the list of authors. This was agreed, and N. A. Logan undertook to circulate a revised draft shortly.

Minute 7. Publications of interest. P. De Vos drew attention to the recent publication of: 'Bacillus: Cellular and Molecular Biology', edited by Peter Graumann [454 pp. Caister Academic Press (2007); ISBN-10 : 1904455123; ISBN-13:978-1904455127]. N. A. Logan announced a proposed title in the Springer Soil Microbiology series: 'Aerobic, Endospore-Forming Soil Bacteria', to be edited by N. A. Logan and P. De Vos, and he asked members of the subcommittee to comment upon the draft outline of the book, the tentative sections being: Diversity; Growth, spores and survival; Interactions; and Contributions to soil ecosystems.

Minute 8. Current membership. The current membership of the subcommittee is as follows: N. A. Logan (Chairman and acting Secretary), Glasgow, UK; A. H. Bishop, Greenwich, UK; H.-J. Busse, Vienna, Austria; P. De Vos, Gent, Belgium; D. Fritze, Braunschweig, Germany; M. Heyndrickx, Melle, Belgium; P. Kämpfer, Giessen, Germany; A.-B. Kolstø, Oslo, Norway; F. G. Priest, Edinburgh, UK; M. S. Salkinoja-Salonen, Helsinki, Finland; L. Rabinovitch, Rio de Janeiro, Brazil; and A. Ventosa, Seville, Spain.

Minute 9. Next meeting. The next meeting of the subcommittee will be held during the XIII International Congress of Bacteriology and Applied Microbiology, Sapporo, Japan, in September 2011.

Minute 10. Adjournment. As no further participants had appeared the open session of the meeting was abandoned, and the meeting was adjourned at 13:05 on 6 August 2008 . 